\title{
A!
}

This is an electronic reprint of the original article.

This reprint may differ from the original in pagination and typographic detail.

Houtbeckers, Eeva

\section{Framing social enterprise as post-growth organising in the diverse economy}

Published in:

MANAGEMENT REVUE

DOI:

10.5771/0935-9915-2018-3-257

Published: 01/01/2018

Document Version

Peer reviewed version

Please cite the original version:

Houtbeckers, E. (2018). Framing social enterprise as post-growth organising in the diverse economy.

MANAGEMENT REVUE, 29(3), 257-280. https://doi.org/10.5771/0935-9915-2018-3-257

This material is protected by copyright and other intellectual property rights, and duplication or sale of all or part of any of the repository collections is not permitted, except that material may be duplicated by you for your research use or educational purposes in electronic or print form. You must obtain permission for any other use. Electronic or print copies may not be offered, whether for sale or otherwise to anyone who is not an authorised user. 


\title{
Framing social enterprise as post-growth organising in the diverse economy
}

\author{
Eeva Houtbeckers \\ eeva.houtbeckers@aalto.fi \\ Department of Design \\ Aalto University \\ PO Box 11000, FI-00076 AALTO
}

\begin{abstract}
Organising for post-growth society is called for to enable living on our finite planet. While previous research has suggested that social enterprise could be one form of post-growth organising (PGo), these suggestions might not rely on critical studies of social enterprise (SE) or studies exploring everyday practices of SE. This paper asks to what extent can SE practices be considered to be post-growth organising and examines two empirical examples of self-employment identified as SE and sensitive to the elements attached to PGo. They functioned to develop more sustainable solutions in the field of coworking for social innovation and up-cycling used clothing. The analysis of actors' everyday 'sayings' and 'doings' reveals how SE is used to channel social and environmental concerns in working life. Moreover, self-employment was not enough to constantly provide a living wage, but actors sustained themselves by navigating the diverse economy. Subsequently, they had to relate to the economic growth imperative at an organisational level. By making visible the ambivalence of the notion 'social enterprise', this study encourages the conducting of research that focuses on the everyday practices perceived as PGo.
\end{abstract}

Keywords: post-growth organising; social enterprise; diverse economy; everyday practices; selfemployment; cooperative; co-working; up-cycling. 


\section{Introduction}

The imperative for economic growth is noted to be one of the root causes of our contemporary problems. Many scholars suggest abandoning economic growth as a policy-making objective since this seems to hold a connection with natural resource overuse, and both human and non-human mistreatment (Latouche, 2009; D’Alisa, Demaria, \& Kallis, 2014). While previous research has focused on the analysis of contemporary growth-oriented lifestyles and the need for new models (see, for example, Jackson, 2009), the body of research analysing the practical solutions for post-growth economy is still emerging (Johnson, Nelund, Olaison, \& Sørensen, 2017).

Attempts to connect post-growth with different organisational patterns are necessary, since we have only an emerging understanding of how post-growth societies could be organised. Social enterprise (SE) has been suggested to be one potential model for post-growth organising ${ }^{1}$ (PGo), since SEs are understood to be, for example, democratic (Johanisova \& Wolf, 2012) and not interested in profit maximisation (Johanisova, Crabtree, \& Franková, 2013). Therefore, this paper assesses to what extent SE practices can be considered to be PGo.

However, not all conceptualisations of SE necessarily stress economic democracy, nor do they reject personal profit altogether, since SEs have different local criteria (Defourny \& Nyssens, 2012). For example, Safri (2015) describes a dialogue, in which solidarity economy activists realise that there are different understandings of SE in Brazil and in the USA. In Brazil, SEs are worker-owned companies, whereas in the USA SEs often comprise charismatic individuals leading organisations that work in the social sector. Moreover, according to previous critical research, SE as a concept emphasises the responsibility of individuals (Jones \& Spicer, 2009) and celebrates the success of 'heroic' entrepreneurs (Dey, 2016), which weakens collective forms of organising. Thus, some suggest that SE is a vehicle for

\footnotetext{
${ }^{1}$ Post-growth organising emphasises the processual aspects of organising beyond the growth ideology
} 
neoliberal values (Grant, 2014), emphasising individual responsibility and shifting the focus from collective responsibility (Grenier, 2009).

Such analyses highlight the tension between framing SE categorically as post-growth organising and the 'everyday aspects' of PGo in SEs. Therefore, I argue that there is a need to study everyday practices. Thus, instead of focusing conceptually on how SE is or is not PGo, this paper aims to fill a recognised gap at the nexus of the social enterprise and post-growth literature. It stems from the call that the practice of SE 'must always and necessarily be studied in the context of its emergence [...] in order to trace the traditional and alternative possibilities which have become silenced' (Dey \& Steyaert, 2010, p. 96). This characterises the need for analysing the 'doings and sayings' (Nicolini \& Monteiro, 2016) of SE practices and how they can be linked to PGo.

This study draws on an analysis of two cases and highlights the experiences of one urban self-employer and some cooperative actors from 2009-2014. The actors were concerned with social and environmental injustices in the sectors of up-cycling clothing and co-working for social innovation. Their initiatives were considered to not only challenge the status quo in their fields, but also question societal problems beyond their everyday work. In order to answer the research question 'To what extent can social enterprise practices be considered to be post-growth organising?', the analysis focuses on (1) how the self-employer and the cooperative actors, moved by sustainability concerns, related to the notion of SE, and (2) how they organised their work over time in the diverse economy.

\section{Framing social enterprise as post-growth organising}

Post-growth organising and social enterprise

Conceptually, post-growth is tightly linked to 'growth', which in itself is an ambivalent concept. According to Borowy and Schmelzer (2017, p. 1), 'the semantic core of economic growth is statistically fixed' and refers to Gross National Product (GNP) or Gross Domestic Product (GDP), which measure 
the monetary value of products and services produced in a nation.' Yet, post-growth thinking entails much more than 'degrowing' GNP or GDP. Instead, the debates refer to paradigm changes with unknown consequences (Latouche, 2009). Accordig to Safri (2015, p. 299), “[t]he prefix of "post" stands more for a different way of perceiving the economy and economic development that does not focus on capitalist growth as the exclusive means by which well-being is improved.'

While, for instance, Reichel (2017) has modelled PGo based on Luhmann's system theories, few studies, with an exhaustive definition for PGo, exist. Contemporary examples of PGo include organisations owned and managed by workers (Atzeni, 2014), communes, complementary currencies, credit unions, and gift giving (Parker, Cheney, Fournier, \& Land, 2014b). Historical examples of organising that challenge the existing ways of power relations exist, such as pirating (Parker, Cheney, Fournier, \& Land, 2014a, p. 27-28). Overall, PGo can be attached to certain fields or sectors, which address environmental and/or social issues in a reflexive manner. In addition, PGo can refer to certain organisational practices, such as cooperatives, community-based initiatives, and social enterprises (Gibson-Graham et al., 2013). In this paper, I refer to post-growth organising (PGo) to highlight people's rising awareness of social and ecological problems that stem from an economic growth fixation and their efforts to address these problems. Such a position requires normative and practical negotiations concerning lived history, now, and the future, since no clear guidelines exist on how to organise for a post-growth society and economy (Johnson et al. 2017; Latouche 2009; Barca, 2017).

PGo does not take place in a vacuum but in relation to the current ways of organising the economy (Fournier, 2008), i.e. also in relation to capitalism (Johnson et al., 2017; Parker et al., 2014a). Although PGo as a concept may overcome some of the problems in the use of 'alternative' as a notion (White \& Williams, 2016), there is still a danger of capitalocentricism. According to Gibson-Graham (2006, p. 6), 'other forms of economy [...] are often understood primarily with reference to capitalism [...] as existing 
in capitalism's space or orbit.' As a result, diverse ways to organise economy and exchange become absorbed into the capitalist project. Gibson-Graham (2006) emphasises that understanding capitalism as an omnipotent power is one of the strategies that takes away strength from other initiatives.

Social enterprise has been suggested to be one potential model of economic organising in/for post-growth societies (Johanisova \& Wolf, 2012; Johanisova et al., 2013; Buch-Hansen, 2013; Dedeurwaerdere et al, 2017). This is because there are a number of criteria that are often attached to SEs, for instance democratic governance, limited profit-distribution, collective ownership, and scaling (social) innovations (Defourny \& Nyssens, 2012), which resonate with discussions on PGo. Supporting SEs is understood as one means for supporting economic democracy, comparable to the cooperative model (Johanisova \& Wolf, 2012). In addition, SEs as PGo can be understood to be not interested in profit maximisation (Johanisova et al., 2013; Dedeurwaerdere et al, 2017) or practising hybridity, i.e. combining 'institutional patterns' and reconfiguring economic systems (Huybrechts, 2013).

These agreeable characteristics presented in previous literature are among the various attributes that have been attached to SE as PGo. Based on these, the link between SE and PGo seems viable. However, next I show how SE is not a value-free concept with only certain meanings.

\section{Problematising social enterprise as post-growth organising}

When social enterprise emerged as a concept in the 1990s, it offered hope for solving some of the wicked problems of our times. The power of SE is in its ability to encourage people to act. SEs have been promoted in national and international policies, for instance in the UK (Teasdale, 2011), and in the European Union. Social entrepreneurs are celebrated as novel thinkers who create new solutions, markets, and institutions. Well-known examples of social entrepreneurs, such as the Nobel Prize-winning Muhammad Yunus, highlight such ideas. In short, SE generates optimism in a world with deeply experienced injustices. The emergence of SE was not a coincidence. SE and other alternative ways for 
framing entrepreneurship, like community-based enterprise, highlight the need to discuss entrepreneurship beyond economic wealth creation (Tedmanson, Essers, Dey, \& Verduyn, 2015). Academically, much effort has been put in defining SE, but no unified definition exists (Nicholls, 2010). One way to frame SE activities is to analyse an enterprise's values, processes, and outcomes (Alegre, 2015). This perspective emphasises that a SE can be recognised because of its mission, its decisions on how to organise different processes, or what kinds of impact it generates - or a combination of these ideal types.

However, Jones and Spicer (2009) argue that the (Western) cultural tradition has the tendency to place responsibility for solving social problems on individuals, i.e. entrepreneurs, instead of thinking that the task belongs to everyone. When some individuals succeed in addressing the wicked problems, they are celebrated as heroes. This shifts the focus away from the responsibilities of communities and governments (Grenier, 2009). According to Dey (2016), understanding the practice of SE as an individual heroic activity undermines much of the radical power of collectives, which the notion of SE could include. This interpretation aligns with the framings of SE as PGo discussed above and with GibsonGraham et al. (2013) discussed in the next sub-chapter.

Yet, despite the attempts to 'save' SE from dominating narratives, concerned critics argue that SE is colonised by neoliberal marketisation (Grant, 2014). Through such use, SE is portrayed as an ideological solution to contemporary challenges with much of the same assumptions that caused the challenges in the first place (Dey, 2016). Acording to Jones and Murtola (2012), entrepreneurship cannot be separated from capitalism. Furthermore, notions such as SE lead to 'naturalising capitalism', although entrepreneurship is a political notion, and use 'economic, and specifically capitalist categories to organise social life' (Jones \& Murtola, 2012, pp. 127-128). Next, I turn to why it matters what we call activities and how this relates to PGo. 


\section{Everyday practices of social enterprises in the diverse economy}

It is crucial to understand what takes place in everyday settings for exploring post-growth organising. This is because concepts, such as 'post-growth' and 'social enterprise', can move at a highly conceptual level, resulting in losing the actors of sight. While the concept of SE partly depends on an ideal individual who does things - thus inadvertently missing people actually doing everyday things that are usually far from ideal - some post-growth discussions might not mention actors at all, i.e. those who do the organising in or for post-growth societies.

In studying everyday practices, the focus is on 'orderly materially mediated doings and sayings $[\ldots]$ and their aggregations' (Nicolini \& Monteiro, 2016, p. 110). The understanding of everyday practices varies based on disciplinary traditions. In this paper, the focus is on actors, i.e. the practitioners or the 'carriers' of practices (Reckwitz, 2002). They function at the intersection of various networks of practices (Brown \& Duguid, 2001), such as a self-employer up-cycling clothing, and connect these networks to enable cross-learning, for example developing both dressmakers' education and local manufacturing towards up-cycling. Following practice thinking, different combinations of SE practices are agreed locally and carried out by practitioners in daily work. For example, limited profit-distribution and democratic decision making might be criteria for SEs in some locations, while in others the practical applications are different. According to Nicolini and Monteiro (2016), the borders of phenomena should be discussed and decided by practitioners and studied by researchers. I add that when researchers are part of the movement as practitioners, they should have a say on what to call phenomena. This resonates with the analysis by Chatterton (2010, p. 1221), who explored anti-capitalist activism. According to him, instead of 'anti-capitalist', activities are better described 'post-' and 'despite-' capitalist.

In the vein of 'despite-'capitalism, one useful tool to examine PGo and SE practice is the notion of diverse economy introduced by Gibson-Graham et al. (2013, p. 13) because it emphasises the process of 
negotiating the meanings and practices of economy/ies. It serves as a tool for analysing labour, enterprise, transactions, property, and finance (Table 1). The diversity of economic practices in each of these categories is explored by naming capitalist, alternative capitalist and non-capitalist practices. Their argument is that while the first sub-category is backed up by many visible institutions, such as private property rights, likewise the other economic practices, illustrated by the examples in the table, are supported by habitual ways of organising, which are by no means marginal in volume or frequency. Yet, these forms seem to have less status and institutional support. Moreover, the activities taking place in the diverse economy shift on this spectrum and the limits are fluid, indicated by the dash line in Table 1.

[Insert Table 1 about here]

For the purpose of this paper drawing from the experiences of a self-employed professional and a number of cooperative actors, I have underlined the alternative ways they managed labour, enterprise, transactions, property, and finance in Table 1. I will elaborate these practices in the findings section.

When research focuses on understanding everyday practices, solid concepts can start to shake. This is at least what happened during and after my fieldwork among people who tried to make a living based on their social and environmental concerns. SE was a notion used - but in a different way than one would expect from reading the highly cited SE articles or even some critical commentators' work.

\section{Empirical material and analysis}

\section{Finnish social enterprise field}

Finland is one of the Nordic countries that often occupies the top places for international comparisons for life expectancy, well-being, and safety. For instance, social, health and welfare services, and education are covered by the government through taxes. Thus, SE has a specific meaning compared to places where government's role in service provision is smaller. In Finland, SE has referred to work- 
integration of the less privileged workforce and social and welfare services developed and offered by third sector organisations (Pättiniemi, 2006). In addition, SE is attached to the cooperative movement: producer and consumer cooperatives with historical roots, and workers' cooperatives, especially after the depression in the 1990s (Inkinen, 2000). The 'new' cooperatives emerging in the 2010s have provided space for alternative values and activities (Moilanen, Peltokoski, Pirkkalainen, \& Toivanen, 2014).

In Finland, there is no direct financial support for SEs or social entrepreneurs. Only social enterprises (WISEs) listed by the government gain slightly better support for employing people with a disadvantaged employee position, which amounts to at least one third of their total number of employees. In addition, they must have money to employ people. Thus, other than WISEs, identifying with the notion of SE is a way to attract customers or to do identity work.

In the 2000s, SE began to be used in relation to activities that differed from the models described above. Increasingly, there were self-employers who had sustainability concerns and identified themselves or were identified as 'social entrepreneurs'. They could have been conceptualised for instance as 'activists with a business'. Yet, some of these self-employers chose the former identity, although at the time they were not recognised as such by other actors. Moreover, the self-employers did not work in the social and welfare sector nor in the work-integration field traditionally attached to SE in Finland.

\section{Empirical material}

I draw from empirical material generated for a research project on contemporary SEs in Finland. During 2009-2014 I followed three Finnish self-employed professionals and one cooperative in the fields of coworking, open data, up-cycling, and veganism. The aim was to understand the new forms of SE practised by young urban self-employers, who had set up their activities to reflect their sustainability concerns. For this paper, I chose two cases for the following reasons (Table 2): first, these actors identified with SE and expressed their discontent towards contemporary growth-oriented societies. 
[Insert Table 2 about here]

Second, they functioned in sectors that relate to addressing environmental and/or social issues, namely enabling co-working and up-cycling recycled clothing. According to Robertson (2014), liveable cities and recycling entail solutions to sustainable development challenges. SocInn (pseudonym) addressed urban planning issues and the work done in social communities by nurturing social innovation in its coworking space. ReDress (pseudonym) focused on advancing the use of recycled clothing, i.e. up-cycling, a sector at the intersection of various networks of practice. However, the selected cases differ in their organisational form - a cooperative and limited liability company - and size - the cooperative had many more actors in its co-working space.

The empirical material used in this paper includes documents, interviews and participant observation. Selected to theorise about SE, I do not wish to directly frame these two cases as instances of post-growth organising. Instead, I present the environmentally concerned self-employer and the cooperative actors as cases that demonstrate the ambivalence of SE, which relates to how we frame SE as PGo. Moreover, I show how activities framed as SE might differ from SE definitions.

\section{Analysis process}

I understand interviews and fieldnotes as cultural material that represent the way respondents and the researcher understand the phenomena (Alasuutari, 1996). Initially, I analysed the open interviews as thematic narratives (Riessman, 2008) and coded the interviews and fieldnotes 'in vivo', i.e. using the participants' concepts. This phase resulted in several dozen codes, which were clustered thematically: for instance initial steps, gaining funding, business idea, customers, and everyday challenges. In this paper, I have used this analysis in order to describe the organisations.

Further analysis for this paper focuses on the 'sayings' and 'doings' of the self-employers over time in relation to PGo. For organising the transcribed interviews and fieldnotes, I employed thematic analysis 
(Attride-Stirling, 2001). I tracked the parts in which the interview or fieldnotes discuss economy, finance, labour, ownership, capital, entrepreneurship, and SE. In the case of SE, actors used it as a category in order to make sense of what their work was about, even when not asked by the researchers. The separation of these themes from the interview narratives is somewhat artificial: they were discussed in disorder, for instance initially explaining SE in principle before describing the everyday struggles related to employing people.

Second, in order to analyse their doings, I draw on my earlier analyses of their entrepreneurial paths, including timelines of their actions that represent the evolvement of their business idea, income, grants and loans, space/store, and collaboration over time (Houtbeckers, 2016b). What is common to all of the cases is the surprising or even counter-intuitive changes in the traced themes over time. For instance, ReDress ended up developing a work-for-welfare programme for unemployed dressmakers, which was not their initial purpose (Houtbeckers, 2016a). These timelines served as a basis for analysing how the self-employer and cooperative actors navigated the diverse economy. When constructing the descriptions, I used the categories from Table 1 to describe their work over time. I found it helpful to follow their 'sayings' over time and compare it to their 'doings'. While I was not there all the time to witness what happened, I was able to inquire about the same themes over time and clarify details. In addition, participant observation aided in developing a sense of social relations in situ.

\section{Findings}

\section{SocInn and ReDress as social enterprises}

Social Innovation Incubator (SocInn) was established by a group of people as a cooperative that offered space for experimentation and social change projects. The first CEO, hired to find a more suitable coworking space and to launch activities, described SocInn: 
a state of mind [...] a do tank [as opposed to a think tank] [...] we often say to people that come and visit us so that you get a feeling of it. It's not only a space but there are community managers. Finding connections between SocInn members is very orchestrated [planned]. (Interview, 2009)

The actors had parallel but also differing ideas on the purpose of the co-working space. The first CEO put it in a newsletter that 'capitalism as we know it has come to an end. [...] We need to construct a different way of developing our societies.' One of the most transcendent visions was articulated by a founding member-manager:

If we solve all the problems, such as poverty and climate change, with technology, do things still work? [...] if we give everyone a magic wand and one can use nanotechnology to create for example a hotel [...], would we still know how to work together? [...] suddenly my neighbour says I want a bigger hotel and then all the resource are used [again] and there are wars [...] so technology does not solve things. The change has to come from within humans. [...] How to find such authenticity and kindness and how to present it? Constructed as a vision: The world full of humane humans. [...] Many crimes in the world can be explained by [...] people shutting down that voice in themselves. This is what I mean by a humane human, people who still hear that voice. (Interview, 2012)

The views have little to do with the capitalist project and can be interpreted to align with the post-growth agenda. Yet, there were also other voices challenging such thinking. One manager commented that many of the aims represented an abstract move away from the experienced status quo characterised by, for example, a view of omnipotent large multinational corporations and powerless governments, which for some was not a vision detailed enough (Table 3).

\section{[Insert Table 3 about here]}

Sanna (pseudonym) established her venture ReDress with a colleague in order to diminish the amount of textile waste. According to her, people have little idea how much textile waste is generated annually: 
But it is a real problem and pure madness that majority of textiles burned for energy are unbroken and useable. And it is burned only because it has been produced so cheaply that after someone has worn it once, no one can ask even two euros for it. It's not even profitable for second-hand shops. (Interview, 2010)

Throughout the years, their service was to up-cycle, i.e. remodel used clothing into new pieces. She had plans to develop this towards less tailored and more serial work, but most of the trials failed. Instead, Sanna developed her own up-cycled clothing brand, which gained recognition both in Finland and abroad over the years.

From the outset, Sanna was active in several sectoral networks in order to develop up-cycling in the clothing and textile sector. In addition, she got involved in educational development. Although most textile manufacturing had been transferred to countries beyond Europe, Finnish institutions kept educating professionals in clothing and textiles. Eventually, the majority were not employed in the sector. She identified a connection between fast-fashion and manufacturing distance thus she advocated local manufacturing in up-cycling.

Although Sanna was active in promoting SE at a later stage, she established the venture before knowing about SE as a notion. It was others who asked her to join a panel on social entrepreneurs.

Mostly, outsiders define us as a social enterprise. For us, it is ReDress [the company]. These types of definitions are needed for society, not because of the activity. (Interview 2010)

Yet, she saw value in using SE and she described the way SE enables the following of one's passion (Table 3). She was also involved in establishing a peer-to-peer network for contemporary social entrepreneurs.

Overall, Sanna was afraid 'how much pioneer structures will have time to develop before they 
[contemporary societal systems] collapse' (interview, 2013). Her critical take on the contemporary ways of organising societies was reflected when asked about possibilities of SE for young people:

Young people are unsatisfied because they feel that they have no purpose. [...] 'It doesn't matter what I do.' [...] No one is born here with a thought that I want to destroy this planet, cause suffering, exploit others. [...] Those ideas come from society, this societal order. For some social enterprise is scary, because it breaks this cycle and states that that your model is not acceptable, you exploit, you take advantage of others, you do whatever you feel like because you get more money. (Interview, 2010)

In conclusion, people in the followed organisations were inspired by the notion of SE at some point in their path. Overall, their language use reflects the ambivalence towards SE: neither is it rejected nor embraced to the fullest.

Activities in the diverse economy

Both the self-employed professionals and cooperative actors took unique paths before their decision to establish an enterprise. However, for them self-employment or establishing a cooperative related to acting upon social and environmental injustices in a meaningful way while using their expertise. Subsequent to their decision to establish an enterprise, they skilfully used available resources, such as materials, volunteers, and knowledge in order to maintain their businesses (Table 1). The underlined examples in Table 1 give one overview of the types of activities in which the organisations engaged. Next, I explore these activities based on the main categories: labour, enterprise, transactions, property, and finance (Gibson-Graham et al., 2013).

\section{$\underline{\text { Labour }}$}

Throughout its existence, the co-working cooperative SocInn had increasing difficulties in sustaining itself subsequent to unpaid loans taken for renovating the workspace. Despite SocInn still having a full- 
time employed CEO from 2010-2012, it relied on volunteer work until its bankruptcy in 2014. The volunteers were community managers, cooperative managers, users of the co-working space, and a handful of active cooperative members. The community managers' task was to link users of the coworking space as well as take care of the workspace, such as the printer and the coffee maker. There were plans to get enough funding to employ some of the community managers, but this was never actualised. After financial troubles surfaced, the first CEO resigned and a new CEO was not hired. Instead, SocInn got a community manager intern covered by a pay subsidy programme available for all enterprises. Due to the lack of hired personnel, the cooperative board members were active in taking care of daily issues. Some of them were periodically compensated by external project funding.

While income from sub-leasing covered SocInn's running expenses, such as rent, there were loans that could not be covered without extra income from projects. This resulted in a need to generate income for the cooperative. Thus, they set up a seminar series, which brought in extra income to the cooperative. This was possible only because organisers did not get personal compensation, but the profits were directed to the cooperative.

Although Sanna and her business partner were the owners of the enterprise, they were unable to pay themselves regularly. Sanna gained a limited income from social security based on family situations, a right for all citizens in Finland. Because Sanna had entrepreneur status (although most of the time she was unable to employ others), she had limited access to unemployment and some social security benefits. By law, social security is determined by compulsory entrepreneur insurance payments, which require a regular income.

ReDress was an organisation for self-employment for Sanna and her business partner, but also for the interns who had been involved with ReDress. ReDress was able to host interns throughout the research period because clothing and textile education includes, often unpaid, internship. Interns basically work 
as volunteers, because they get study support from the government. ReDress benefited from their work, but Sanna also considered that mentoring interns was an important part of her work as an advocator of up-cycle design.

\section{Enterprise}

SocInn and ReDress identified themselves as social enterprises. Yet, relating to SE did not seem to result in support.

I was involved in establishing a network for social entrepreneurs, which at some point provided peer-to-peer support. But just today I gave feedback that the network could organise something only for entrepreneurs and not only for those interested in social enterprise. Something for sharing experiences, like 'how about the system for paying value added taxes, what do you think of it, oh yeah, we had this and that.' That what is needed in the field. (Sanna, interview, 2010).

Sanna's narrative reflects the way living in a diverse economy can feel lonely in cases when there is little support. She sought support in the up-cycling community consisting of other self-employers. Yet, the sectoral communities also had other actors, such as students and civil servants. Self-employment based on social and environmental concerns brought in a layer of sustaining oneself that differed from others and resulted in reflections on entrepreneurship.

SocInn was established as a cooperative. Ideally, it was meant to act as a worker cooperative, but in practice most of the cooperative members were passive. Before bankruptcy, there were plans to change the cooperative to a limited liability company. Despite many cooperative members supporting the plan, there were a couple of members who prevented the change.

\section{$\underline{\text { Transactions }}$}

In addition to market-based transactions, SocInn and ReDress had alternative and non-capitalistic 
transactions. Whenever SocInn had open breakfast or lunch meetings, people were asked to bring in food (barter in Table 1). Subsequent to the space being subleased to external users, leftovers were shared between users in the next SocInn meeting (gleaning in Table 1). At ReDress, Sanna relied on recycled clothing as an inexpensive or free material for her own up-cycled clothing collection. When she could, she got the material for free from the recyclers or from customers (gift giving in Table 1).

\section{Property}

SocInn and ReDress had a modest amount of property, but they did own some equipment, such as office furniture and sewing machines. Both organisations rented the space they used (tenanted in Table 1). Interestingly, they relied heavily on open source intellectual property. SocInn drew in professionals from different sectors to visit the workspace and share their knowledge in sessions meant for learning. Sanna relied on knowledge on changes in legislation concerning textiles, and she had a habit of contacting professionals to learn about on-going up-cycling related processes.

\section{Finance}

Neither of the organisations relied on loans from the mainstream market but gained funding from alternative markets or non-market finance (Table 1). One of the key elements in SocInn's cosy coworking space was good coffee and tea. Complimentary drinks were served to everyone who entered the space. One of the founders wanted SocInn to offer the best coffee in town. But since serving locally roasted artisan coffee was an expense, SocInn had a piggy bank for donations (donations in Table 1). Yet, these were small amounts compared to the loans taken for renovation. Thus, they organised a successful crowd-funding campaign with nominal interest to cover SocInn's renovation expenses.

Sanna had built her enterprise with scarce financial resources, such as government-secured entrepreneurial loans for women and family lending. She had an ambivalent relationship to the financial 
development of her enterprise.

I understand ReDress as a [...] figure [...], in which I see the balance sheet and returns. And last January-December, it [figure] went on its knees. [...] It was falling apart and I had to keep it together. [...] At the moment, I'm anxious if it will stand up. [...] I'm cheering it: 'Keep it together, continue to run, you cannot lie down.' [...] This [enterprise] has enormously been based on my coping and well-being. And my wellbeing is correlating with how well the enterprise runs. (Interview, 2013)

For her, finance issues were related to an inability to employ others. Yet, she found ways to circumvent a lack of finances by other means, such as inviting a new business partner who earned her share with work (sweat equity, Table 1). Although the times seemed tough, they did not consider it too risky.

At the moment, we have a loan of 10000 euros, that's 5000 euros per partner. People out there take 5 000-euro loans to go shopping. If we have been able to wake up people at all during the past years, it has definitely been worth the 5000 euros [laughs]. (Interview, 2010)

Navigating the diverse economy and the ambivalence of social enterprise

Despite imaginative solutions, navigating the diverse economy was not carefree for people in SocInn or ReDress. Their everyday work was affected by various challenges, such as a lack of money for compensating themselves or volunteers for their work. One of the SocInn owner-managers commented that 'it is a bit twisted [...] why should we do voluntary work to help others' business?' (SocInn manager, interview, 2013). They referred to the way the co-working space was used by entrepreneurs, freelancers, and self-employers who did not participate in the joint projects but benefited because they could sublease the space inexpensively. In short, the willingness to host (potential) social innovators resulted in some working unpaid to maintain the workspace. Such a use of volunteer work is often attached to nonprofit organisations, but its role in SEs is more ambivalent because of the market-based activities and the 
possibility of financial benefits for the owners. Without discussion, rules or limits on sharing profits, using volunteer work for generating profits and distributing then among the owners seems problematic or even exploitative. However, in the case of SocInn, there were no profits, and in the case of ReDress only small profits, which were not distributed to the owners during the research period.

In addition, sharing knowledge was a two-way route: because Sanna was active in movements promoting up-cycle design, she had difficulties in devoting enough time for dressmaking, which brought her income. A similar issue plagued SocInn, since they organised a number of high profile SE events, which required work from SocInn active volunteers.

While Sanna saw no other way than self-employment due to her strong opinions about the fashion industry, her future plans were not always bright.

Well, it is always possible that this is the final term [...] No, no, no [...] But maybe at the moment, if I could just get this company to become solid, that'd be nice. And I'm not interested in the financial advancement as such. It'd be always a plus. But I'm interested in that we'd gain a financial stability in which we don't have to constantly think about company future [...] Inevitably, due to our economy structures, we need that small growth in everything. Economic growth, that needs to be visible everywhere [says the last sentence while whistling between her teeth]. (Sanna, interview, 2013)

Sanna's narrative reflects a view on economic growth as something unavoidable, although not completely acceptable. In the cooperative, their relationship to economic growth seemed ambiguous and depended on to whom I was talking. While SocInn hosted people questioning the growth paradigm, after the financial troubles, a new manager stated that cooperatives were not 'real enterprises.' According to them, work did not accumulate as in cooperatives and resulted in more monetary value. For them, the nonmonetary value of labour, transactions, property, and finance were not tangible enough. Such different views caused conflicts in internal meetings on how to run daily matters, for instance on how to fix broken equipment. 


\section{Discussion: Social enterprise practices as post-growth organising in the diverse economy}

In this paper I understand post-growth organising (PGo) as a means for highlighting people's rising awareness of social and ecological problems that stem from the fixation on economic growth as well as their efforts to address these problems. Such a position requires normative and practical negotiations concerning lived history, now, and the future, since no clear guidelines exist on how to organise for postgrowth society and economy. In this section I discuss to what extent SE practices can be considered to be PGo. Findings from the analysis resulted in three themes that emphasise the negotiation taking place in everyday work: (1) using SE as a self-employed professional to channel social and environmental concerns in working life; (2) sustaining oneself by navigating the diverse economy; and (3) relating to the economic growth imperative.

\section{Social enterprise as a channel for social and environmental concerns}

The self-employed professional and some cooperative actors used social enterprise as a vehicle for channelling their social and environmental concerns in working life. While they found it a useful concept for communicating about their work, they did not embrace it to the fullest. In fact, for the practitioners labels seemed secondary. Instead, they seemed to 'fill' the definition by describing their social and environmental concerns and the ways to address them with their expertise in working life.

In the case of SE, there are a number of ways to understand and practise it. This is the strength as well as the burden of the phenomenon. Even though the SE concept is considered by some critics to be colonised by neoliberal values, it has generated hope. The SE movement has sparked grassroots' activities, which have resulted in new approaches to contemporary problems. When entrepreneurship is a commonly acceptable way of doing things in contemporary society, enterprise attached to 'social' could act as a veil for activities that challenge the status quo.

People use concepts, such as social enterprise and post-growth organising, in order to communicate their 
agendas. While post-growth directs attention to difficult discussions on how to achieve such a society in practice, SE may seem less of a dangerous notion. Thus, using SE can be a socially acceptable way to frame self-employment when, in fact, some actors aim to contribute to a fundamental paradigm change challenging the continuous economic growth imperative. In other words, instead of framing an activity for example as 'anti-', 'post-' or 'despite-capitalist' (Chatterton, 2010), SE is used for communicating 'alternative' agendas. However, as the findings show, such work means navigating the diverse economy.

\section{Sustaining oneself by navigating the diverse economy}

In addition to paying attention to the used labels, here SE, there is a need to have a closer look at everyday practices. Organising for post-growth societies requires negotiation. Such negotiation takes place in everyday settings, such as how to price enterprise services or how to share resources accumulated in some places, while lacking in others. In this paper, I approached the everyday practices of PGo by analysing how the self-employer and cooperative actors organised their work over time in the diverse economy.

Choosing self-employment, also when it is based on social and environmental concerns, incorporates a layer for sustaining oneself. Yet, by analysing the everyday practices in the studied cases, it became apparent that the self-employer and the cooperative actors were not able to provide a constant living wage via their enterprise. This is not that surprising in the Finnish context, where on average small-scale self-employment results in a lower income compared to waged labour. Despite an insufficient living wage, the self-employer and cooperative actors continued to function, which would have not been possible without navigating the diverse economy. Such navigation - in reference to labour, enterprise, transactions, property, and finance - required constant work. In other words, navigating the diverse economy was enabled by rethinking and redefining the common understanding of work, which is usually attached to waged labour. It mattered what kind of work was done and for what ends. 
In effect, the followed organisations would have had more alternatives to organise their economic activities. Following the spectrum of diverse economy presented in Table 1, they did not for instance utilise time banks available in their cities. While the cooperative used a peer-to-peer loan platform for funding its renovation, it was more of an experiment.

Overall, the descriptions of SE practices in this paper do not fit the image of SE as a heroic activity that overcomes all challenges. Although at times the statements reflect their loneliness, which should not be undermined as a feeling, they did function as part of communities in various forms. As a result, this paper answers the call to denaturalise SE discourse (Dey \& Steyaert, 2010) by examining SE framing as PGo. This paper challenges the interpretation of SE as an individualistic journey by showing how over time people with SE identity are able to survive because they can navigate through the diverse economy. Dey (2016, p. 573) argues that 'making a living in hard times' misses the radical potential of entrepreneurship. As a contrast, I argue that getting by in the diverse economy is exactly how people are able to make a change. I see a danger in romanticising efforts that challenge the growth paradigm - either by setting prerequisites for acceptable models of PGo or arguing that in order to be PGo, there has to be a struggle.

Despite the practical challenges deriving from the navigation the diverse economy, the mere choice of self-employment based on environmental and social concerns can be understood as one means for deviating from capitalist ways of organising (Gibson-Graham, 2006, pp. 249-250). Refusing to comply with the suggested categories can be empowering and inspiring (Tedmanson et al., 2015). Thus, entrepreneurship, also in the form of self-employment, can become a means to actively shape the world around oneself(Calás, Smircich, \& Bourne, 2009). Self-employment and establishing a cooperative were choices for the people followed, based on their social and environmental concerns. As Dey (2016, p. 576) argues, 'any attempt that purports to capture the radical political possibilities of entrepreneurship must 
engage, in one way or another, with the complex questions of neoliberal capitalism as the organizing principle of society.' This tendency was obvious in SocInn and ReDress. During the research period (2009-2014), SocInn went bankrupt, while ReDress continued to exist, but in a manner, that does not resemble continuous growth.

\section{Relating to the economic growth imperative}

The findings reveal how the self-employer and the cooperative actors relate to the economic growth imperative. The self-employer reluctantly states that we need growth in everything. In the cooperative, one manager did not consider it a 'real enterprise' because of the cooperative format. This implicitly reflects that a 'real enterprise' needs to accumulate wealth. According to Reichel (2017, p. 100), an economic growth imperative on a societal level is reflected in the everyday practices of an organisation. Thus, when framing SEs as PGo, actors need to engage in the negotiations of PGo.

Overall, based on previous thinkers, I argue that negotiations are needed on what is PGo and how it can be achieved. While the self-employer and the cooperative actors at times felt lonely with their (social) enterprises, there are many others that try to challenge the taken-for-granted assumptions related to contemporary ways of living and organising. However, the challenge is that the struggles and reclaiming operations are particular and rarely universal. According to Stengers (2017, p. 141), 'reclaiming operations are initiated at the leading edge of the cut [...] my trust is in the plurality of reclaiming operations and the ways in which they connect, weaving relations with and learning from each other.' The burning question of PGo is how to enable negotiations between actors for a paradigm change that challenges the continuous economic growth imperative.

In the same vein of navigating the diverse economy, one place for negotiation is how work and labour are understood in post-growth societies. According to Barca (2017, p. 3), post-growth society 'can only start from fostering dealienation by reopening the possibility for workers control and economic 
democracy, from the workplace to society at large.' She continues that engaging with consumption habits only is politically weak and not enough, since the global perspectives of workers need to be brought in. Moreover, when continuous economic growth is based on the use of limited reserves of fossil fuels, she asks what happens to wage-dependent workers when fossil-dependent industries are diminishing or even banned. She calls for "enlarging the concept of class relations beyond the wage labor relation and toward a broader conception of work' when transitioning towards post-growth societies (Barca, 2018, p. 7).

\section{Conclusions}

Because social enterprise (SE) is sometimes used as an example of post-growth organising (PGo), this paper addressed how and to what extent SE practices can be understood as PGo. In this paper I treated post-growth organising as a means for highlighting people's rising awareness of social and ecological problems that stem from the fixation on economic growth as well as their efforts to address these problems. The findings highlight the normative and practical negotiations concerning how to organise for post-growth society and economy. This paper finds that SEs can be used as a channel for acting upon social and environmental concerns in working life. Yet, the analysis reveals that neither self-employment nor the cooperative were enough to provide the respective actors a living wage. Yet, they were able to sustain themselves by navigating the diverse economy. Their navigation included various practices related to labour, enterprise, transactions, property, and finance. Finally, they had to relate to the economic growth imperative at an organisational level.

This paper contributes to a number of literature streams and their intersections. First, this paper explored SE as PGo. Previous studies indicate that there is a connection between these notions, but the connection is explored to a lesser degree. The aim of this paper was not to define a formula to make it possible to state which SEs can be referred to as PGo. Instead, I argued that defining PGo requires negotiation. In order to emphasise the ongoing negotiation taking place in relation to SE, this paper takes seriously the 
critical studies conducted on SE. Previous analyses of SE discourse show that there is a variety of needs for distinguishing certain activities from others by labelling them as 'social enterprise', so as to mark entrepreneurial activities beyond wealth-creation or limited profit-distribution. Previous (critical) studies on SE and the chosen focus on practices in this paper highlight that using a label, here SE, is not a sufficient criterion for labelling something as PGo.

Second, an understanding of PGo builds up gradually, and this paper is one step in this process. Negotiating a paradigm change for a post-growth society takes place on many frontiers and SE has emerged as one situation, since some suggest that SE is one form of PGo. In the light of critical analyses of SE, a mere reference to SE is not enough. Therefore, there is a need to study everyday practices in order to make sense of SE as PGo or PGo in general. By presenting an analysis of everyday activities of two cases that use the notion SE, this paper showed a mismatch between the connotations of SE and what actually took place in everyday settings. By making visible the ambivalence of the SE notion, this study encourages research that focuses on everyday activities perceived as SE and framed as post-growth organising. Reiterating White and Williams (2016, p. 329), who comment that with the use of the notion 'alternative' it is possible that 'something significant and authentic is being obscured or lost regarding lived practices', I encourage researchers studying post-growth organising to focus on the everyday practices and the experiences of people navigating the diverse economy.

Third, this draws on the notion of diverse economy and echoes Safri's (2015, p. 316) message that 'no economic forms' should be 'structurally excluded' but the activities of 'ethico-political negotiation over needs or surplus' should take place across the diverse economy (Table 1). Indeed, SE and PGo studies would benefit from considering what is meant by 'economy' along the lines of Gibson-Graham (2006) and Gibson-Graham et al. (2013). In practice, the activities attached to SE and PGo can be analysed by using Table 1, which could aid in understanding how to organise for post-growth societies. 'Post-' and 
'despite-' capitalist activities (Chatterton, 2010) are reflected in the way the self-employer and cooperative actors navigated through the diverse economy. It is important to remember that such navigation is common everywhere. For instance, Gibson-Graham (2006) refer to unpaid labour in the finance sector, which is considered 'pro'-capitalist.

While SE discourse travels globally, the local and personal ways of practising this notion, as well as to the notion of PGo, are limited to the used empirical material. The empirical material of this study consists of urban people and does not include examples from the countryside. Also, at the time of the study, most of the participants were under 40 years old. While this prevents the possibility for gaining a more thorough picture of SE in the diverse economy, the empirical material reflects one particular Finnish setting in which ventures were initiated because of sustainability concerns.

Further research could analyse in depth, for example with a participatory research design, how actors move in the diverse economy and what kinds of paradoxes emerge. Also, exploring everyday practices reveals the different modalities and combinations that exist between two often mentioned extremes: namely, waged work under corporate control with a sufficient income and unpaid labour in emancipated self-governed collectives. Although the empirical material used in this paper offers some insight concerning the changes in self-employer's and cooperative actors' activities over time, analysis in greater detail would be illuminating for the development of research on post-growth organising.

\section{Acknowledgements}

In addition to the special issue editors and two anonymous reviewers, I thank Tuomo Alhojärvi, Anne Kokkonen and Michael Roy for the comments provided during the process. 


\section{References}

Alasuutari, P. (1996). Theorizing in qualitative research: A cultural studies perspective. Qualitative Inquiry, 2(4), 371-384.

Alegre, I. (2015). Social and economic tension in social enterprises: Does it exist? Social Business, 5(1), $17-32$.

Attride-Stirling, J. (2001). Thematic networks: an analytic tool for qualitative research. Qualitative Research, 1(3), 385-405.

Atzeni, M. (2014). An introduction to theoretical issues. In M. Atzeni (Ed.), Alternative work organizations (pp. 1-24). London: Palgrave Macmillan.

Barca, S. (2017). The Labor(s) of Degrowth. Capitalism Nature Socialism, 1-10. https://doi.org/10.1080/10455752.2017.1373300

Borowy, I., \& Schmelzer, M. (Eds.). (2017). Introduction: the end of economic growth in the long-term perspective. In History of the future of economic growth: historical roots of current debates on sustainable degrowth (pp. 1-26). London; New York, NY: Routledge, Taylor \& Francis Group.

Brown, J. S., \& Duguid, P. (2001). Knowledge and organization: A social-practice perspective. Organization Science, 12(2), 198-213.

Buch-Hansen, H. (2014). Capitalist diversity and de-growth trajectories to steady-state economies. Ecological Economics, 106, 167-173.

Calás, M. B., Smircich, L., \& Bourne, K. A. (2009). Extending the boundaries: Reframing 'entrepreneurship as social change' through feminist perspectives. Academy of Management Review, 34(3), 552-569.

Chatterton, P. (2010). So what does it mean to be anti-capitalist? Conversations with activists from urban 
social centres. Urban Studies, 47(6), 1205-1224.

D’Alisa, G., Demaria, F., \& Kallis, G. (2014). Degrowth: A vocabulary for a new era. Routledge.

Dedeurwaerdere, T., De Schutter, O., Hudon, M., Mathijs, E., Annaert, B., Avermaete, T., ... Vivero, J.L. (2017). The Governance Features of Social Enterprise and Social Network Activities of Collective Food Buying Groups. Ecological Economics, 140, 123-135.

Defourny, J., \& Nyssens, M. (2012). Conceptions of social enterprise in Europe: A comparative perspective with the United States. In B. Gidron \& Y. Hasenfeld (Eds.), Social Enterprises: An Organizational Perspective (Vol. 1, pp. 71-90). Palgrave Macmillian.

Dey, P. (2016). Destituent entrepreneurship: disobeying sovereign rule, prefiguring post-capitalist reality. Entrepreneurship \& Regional Development, 28(7-8), 563-579.

Dey, P., \& Steyaert, C. (2010). The politics of narrating social entrepreneurship. Journal of Enterprising Communities: People and Places in the Global Economy, 4(1), 85-108.

Fournier, V. (2008). Escaping from the economy: the politics of degrowth. International Journal of Sociology and Social Policy, 28(11/12), 528-545.

Gibson-Graham, J. K. (2011). A feminist project of belonging for the Anthropocene. Gender, Place \& Culture, 18(1), 1-21.

Gibson-Graham, J. K., Cameron, J., \& Healy, S. (2013). Take back the economy: an ethical guide for transforming our communities. Minneapolis ; London: University of Minnesota Press.

Gibson-Graham, J.-K. (2006). The end of capitalism (as we knew it): A feminist critique of political economy (2nd edition). Minneapolis: University of Minnesota Press.

Grant, S. (2014). Social enterprise through a critical appreciative lens. In S. Denny \& F. Saddon (Eds.), Social Enterprise: Accountability and Evaluation Around the World (pp. 213-230). Abingdon: 
Routledge.

Grenier, P. (2009). Social entrepreneurship in the UK: from rhetoric to reality? In R. Ziegler (Ed.), An introduction to social entrepreneurship: Voices, preconditions, contexts (pp. 174-206). Cheltenham: Edward Elgar.

Houtbeckers, E. (2016a). The everyday experiences of a sustainable entrepreneur: Brokering for social innovation at the intersection of networks of practice. In K. Nicolopoulou, M. Karatas-Özkan, F. Janssen, \& J. Jermier (Eds.), Sustainable Entrepreneurship and Social innovation (pp. 320-337). London: Routledge.

Houtbeckers, E. (2016b). The tactics of ecopreneurs aiming to introduce new practices. Small Enterprise Research, 23(1), 22-38.

Huybrechts, B. (2013). Social Enterprise, Social innovation and alternative economies: Insights from fair trade and renewable energy. In H.-M. Zademach \& S. Hillebrand (Eds.), Alternative economies and spaces. New perspectives for a sustainable economy (pp. 113-130). Bielefeld, Germany: Transcript.

Inkinen, K. (2000). Diffuusio ja fuusio. Osuuskauppainnovaation levinneisyys ja sen dynamiikka 1901 1998: alueellisesti tulostuva näkökulma suomalaisen osuuskauppatoiminnan kehityksen ja sisällön muutokseen. Helsinki: Helsinki School of Economics and Business Administration.

Jackson, T. (2009). Prosperity without growth? The transition to a sustainable economy. Sustainable Development Commission.

Johanisova, N., Crabtree, T., \& Franková, E. (2013). Social enterprises and non-market capitals: a path to degrowth? Journal of Cleaner Production, 38, 7-16.

Johanisova, N., \& Wolf, S. (2012). Economic democracy: A path for the future? Futures, 44(6), 562570. 
Johnson, C. G., Nelund, M., Olaison, L., \& Sørensen, B. M. (2017). Editorial: Organizing for the postgrowth economy. Ephemera Theory \& Politics in Organization, 17(1), 1-21.

Jones, C., \& Murtola, A.-M. (2012). Entrepreneurship and expropriation. Organization, 19(5), 635-655. Latouche, S. (2009). Farewell to Growth. Cambridge: Polity Press.

Nicholls, A. (2010). The Legitimacy of Social Entrepreneurship: Reflexive Isomorphism in a PreParadigmatic Field. Entrepreneurship Theory and Practice, 34(4), 611-633.

Nicolini, D., \& Monteiro, P. (2016). The Practice Approach: For a Praxeology of Organisational and Management Studies. In H. Tsoukas \& A. Langley (Eds.), The SAGE Handbook of Process Organization Studies (pp. 110-126). London: SAGE.

Moilanen, H., Peltokoski, J., Pirkkalainen, J., \& Toivanen, T. (2014). Uusi osuuskunta: tekijöiden liike [New cooperative: maker's movement]. Helsinki: Into Kustannus Oy.

Parker, M., Cheney, G., Fournier, V., \& Land, C. (2014a). Part I: Introduction. In M. Parker, G. Cheney, V. Fournier, \& C. Land (Eds.), The Routledge Companion to Alternative Organization (pp. 141). London: Routledge.

Parker, M., Cheney, G., Fournier, V., \& Land, C. (Eds.). (2014b). The Routledge Companion to Alternative Organization. London: Routledge.

Pättiniemi, P. (2006). A plurality of logics behind Finnish social enterprises. In M. Nyssens (Ed.), Social enterprise (pp. 157-166). London: Routledge.

Reckwitz, A. (2002). Toward a Theory of Social Practices: A Development in Culturalist Theorizing. European Journal of Social Theory, 5(2), 243-263.

Reichel, A. (2017). Shape of things to come: From the 'laws of form' to management in the post-growth economy. Ephemera Theory \& Politics in Organization, 17(1), 89-118. 
Riessman, K. K. (2008). Narrative Methods for the Human Sciences. Los Angeles: SAGE Publications. Robertson, M. (2014). Sustainability Principles and Practice. London: Routledge.

Safri, M. (2015). The politics of mapping solidarity economies and diverse economies in Brazil and the Northeastern United States. In G. Roelvink, K. S. Martin, \& J. K. Gibson-Graham (Eds.), Making Other Worlds Possible. Performing Diverse Economies (pp. 296-321). Minneapolis: University of Minnesota Press.

Stengers, I. (2017). Another science is possible: a manifesto for slow science (English edition). Cambridge, UK: Polity.

Teasdale, S. (2011). What's in a Name? Making Sense of Social Enterprise Discourses. Public Policy and Administration, 27(2), 99-119.

Tedmanson, D., Essers, C., Dey, P., \& Verduyn, K. (2015). An uncommon wealth . . Transforming the commons with purpose, for people and not for profit! Journal of Management Inquiry, 24(4), $439-444$.

White, R. J., \& Williams, C. C. (2016). Beyond capitalocentricism: are non-capitalist work practices 'alternatives'? Area, 48(3), 325-331. 
Table 1: The diverse economy (Gibson-Graham, 2011, p. 13; Gibson-Graham et al., 2013; compiled and complemented by the Author) and underlined examples met in the two cases

\begin{tabular}{|c|c|c|c|c|}
\hline LABOUR & ENTERPRISE & TRANSACTIONS & PROPERTY & FINANCE \\
\hline $\begin{array}{l}\text { Wage } \\
\text { Paid labour }\end{array}$ & $\begin{array}{l}\text { Capitalist } \\
\text { Limited liability } \\
\text { company } \\
\text { Exchange-listed } \\
\text { company }\end{array}$ & $\begin{array}{l}\text { Market } \\
\text { Currencies }\end{array}$ & $\begin{array}{l}\text { Private } \\
\text { Private property } \\
\text { Equipment owned } \\
\text { by the users }\end{array}$ & $\begin{array}{l}\text { Mainstream } \\
\text { market } \\
\text { Banks } \\
\text { Exchange-listed } \\
\text { banks } \\
\text { Investment banks }\end{array}$ \\
\hline $\begin{array}{l}\text { Alternative paid } \\
\text { Self-employed } \\
\underline{\text { Cooperative }} \\
\underline{\text { Reciprocal }} \\
\underline{\text { labour }} \\
\text { In-kind } \\
\underline{\text { Work for }} \\
\underline{\text { welfare }}\end{array}$ & $\begin{array}{l}\text { Alternative } \\
\text { capitalist } \\
\text { State-owned } \\
\text { Environmentally } \\
\text { and/or socially } \\
\text { responsible firm } \\
\text { Non-profit }\end{array}$ & $\begin{array}{l}\text { Alternative market } \\
\text { Fair/direct trade } \\
\text { Reciprocal } \\
\underline{\text { exchange }} \\
\text { Alternative } \\
\text { currencies } \\
\text { Community- } \\
\text { supported } \\
\text { agriculture } \\
\text { Barter } \\
\text { Underground } \\
\text { market } \\
\text { Informal market }\end{array}$ & $\begin{array}{l}\text { Alternative private } \\
\text { Publicly accessible } \\
\text { privately-owned } \\
\text { property } \\
\text { State-owned } \\
\text { State-managed } \\
\text { assets } \\
\text { Tenanted } \\
\text { Customary (clan) } \\
\text { land } \\
\text { Community land } \\
\text { trusts }\end{array}$ & $\begin{array}{l}\text { Alternative market } \\
\text { State banks } \\
\text { Government- } \\
\underline{\text { sponsored lenders }} \\
\text { Cooperative banks } \\
\text { Credit unions } \\
\text { Community-based } \\
\underline{\text { financial }} \\
\underline{\text { institutions }} \\
\text { Micro-finance }\end{array}$ \\
\hline $\begin{array}{l}\text { Unpaid } \\
\text { Housework } \\
\text { Family care } \\
\text { Neighbourhood } \\
\text { work } \\
\underline{\text { Volunteer }} \\
\underline{\text { Self- }} \\
\text { provisioning } \\
\text { Slave labour }\end{array}$ & $\begin{array}{l}\text { Non-capitalist } \\
\text { Worker } \\
\text { cooperatives } \\
\text { Social enterprise } \\
\text { Community } \\
\text { enterprise } \\
\text { Self-employed } \\
\text { business } \\
\text { Slave enterprise } \\
\text { Feudal estate }\end{array}$ & $\begin{array}{l}\text { Non-market } \\
\text { Household sharing } \\
\text { Gift giving } \\
\text { Gleaning } \\
\text { State allocations } \\
\text { Hunting, fishing, } \\
\text { gathering } \\
\text { Theft, piracy, } \\
\text { poaching }\end{array}$ & $\begin{array}{l}\text { Open access } \\
\text { Atmosphere } \\
\text { International waters } \\
\text { Open source } \\
\text { intellectual property } \\
\text { Ecosystem services }\end{array}$ & $\begin{array}{l}\text { Non-market } \\
\text { Sweat equity } \\
\text { Community- } \\
\text { supported } \\
\text { business } \\
\text { Rotating credit } \\
\text { funds } \\
\text { Family lending } \\
\text { Donations } \\
\text { Interest-free loans }\end{array}$ \\
\hline
\end{tabular}


Table 2: Empirical material

\begin{tabular}{|c|c|c|c|c|c|c|}
\hline 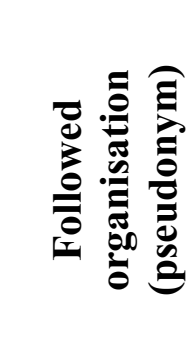 & 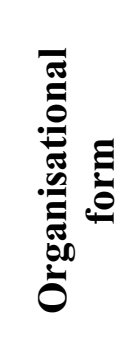 & 离 & 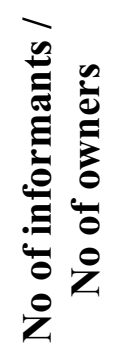 & 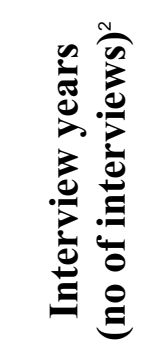 & 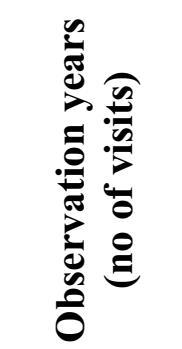 & 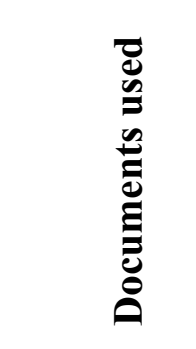 \\
\hline $\begin{array}{l}\text { Sanna, } \\
\text { ReDress }\end{array}$ & Ltd & $\begin{array}{l}\text { Up-cycle } \\
\text { design, } \\
\text { clothing } \\
\text { recycling }\end{array}$ & $2 / 2$ & $\begin{array}{l}2010(2) \\
2011(1) \\
2013(3) \\
2014(1)\end{array}$ & $\begin{array}{l}2011(1) \\
2013(2)\end{array}$ & $\begin{array}{l}\text { Webpage, } \\
\text { Facebook } \\
\text { page, } \\
\text { newspaper } \\
\text { articles }\end{array}$ \\
\hline SocInn & Co-op. & $\begin{array}{l}\text { Co- } \\
\text { working, } \\
\text { project } \\
\text { work, } \\
\text { social } \\
\text { incubation, } \\
\text { urban } \\
\text { developmen } \\
\text { t }\end{array}$ & $8 / 29$ & $\begin{array}{l}2010(1) \\
2011(3) \\
2012(6) \\
2013(4) \\
2014(1) \\
2015(1)\end{array}$ & $\begin{array}{c}2009(3) \\
2011(12) \\
2012(12) \\
2013(4)\end{array}$ & $\begin{array}{l}\text { Webpage, } \\
\text { photos, } \\
\text { brochures, } \\
\text { internal } \\
\text { documents }\end{array}$ \\
\hline
\end{tabular}

${ }^{2}$ Interviews in 2010-2011 with Sanna were generated by another researcher, except in 2011 jointly by the other researcher and the Author and subsequently by the Author. All interviews concerning SocInn are generated by the Author. 
Table 3: Quotes concerning social enterprise

\begin{tabular}{|c|c|c|}
\hline & Relying on identification & Critical of identification \\
\hline Sanna & $\begin{array}{l}\text { If we think of entrepreneurship in } \\
\text { conventional ways, so it is pretty } \\
\text { conditioned how one can behave. } \\
\text { And if one jumps [to unknown], so } \\
\text { fewer people have that type of } \\
\text { courage to just like -- jump to do } \\
\text { how one's mind or heart says. But } \\
\text { that social enterprise kind of } \\
\text { enables that. So OK, this is OK to } \\
\text { do it like this. There are also other } \\
\text { people who do things their own } \\
\text { way. So I'm not crazy. -- And it is } \\
\text { OK to be an idealist and think that } \\
\text { this world can be made a better } \\
\text { place. (Sanna, interview 2010a) }\end{array}$ & $\begin{array}{l}\text { So this enterprise was established } \\
\text { before there was a [contemporary] } \\
\text { social enterprise consciousness [in } \\
\text { Finland]. So the concept was not } \\
\text { used anywhere. (Sanna, interview } \\
2013 \text { b) }\end{array}$ \\
\hline SocInn & $\begin{array}{l}\text { SocInn is often described as } \\
\text { unique. -- If one searches co- } \\
\text { working space for social } \\
\text { entrepreneurs, I don't know of any } \\
\text { other place to choose in this city. -- } \\
\text { If I weren't here, I most likely } \\
\text { wouldn't be in any other co- } \\
\text { working space. (SocInn manager } \\
\text { A, interview 2012) }\end{array}$ & $\begin{array}{l}\text { If we define this [SocInn] so that } \\
\text { we lease a space in the city centre, } \\
\text { slice the space to smaller segments, } \\
\text { and sub-lease it - so what is social } \\
\text { about it? [...] It is business as usual. } \\
\text { But if we add that we try to build a } \\
\text { community, then one can } \\
\text { reconsider. (SocInn manager B, } \\
\text { interview 2013) }\end{array}$ \\
\hline
\end{tabular}

